\title{
ДОСВІД ПІДГОТОВКИ ТА СКЛАДАННЯ СТУДЕНТАМИ- ПРОВІЗОРАМИ ЄДИНОГО ДЕРЖАВНОГО КВАЛІФІКАЦІЙНОГО ІСПИТУ В УМОВАХ КАРАНТИНУ ТА ДИСТАНЦІЙНОГО НАВЧАННЯ У ДНІПРОВСЬКОМУ ДЕРЖАВНОМУ МЕДИЧНОМУ УНІВЕРСИТЕТІ
}

\author{
T. M. Potapova, N. V. Lohvynenko \\ Dnipro State Medical University \\ EXPERIENCE OF PREPARING AND PASSING BY STUDENTS- \\ PHARMACISTS OF THE UNIFIED STATE QUALIFICATION \\ EXAMINATION UNDER QUARANTINE AND DISTANCE LEARNING \\ AT DNIPRO STATE MEDICAL UNIVERSITY
}

\begin{abstract}
Анотація. У статті проведено аналіз результатів єдиного державного кваліфікаційного іспиту (ЄДКІ) для оцінки рівня знань у студентів-провізорів під час складання ліцензійного інтегрованого іспиту «Крок 1» та порівняння цих результатів із національними показниками під час карантину та в умовах дистанційного навчання. Незважаючи на те, що у 2020 р. в Україні вперше було впроваджено дистанційне навчання на період повного локдауну, у зв'язку з поширеністю інфекції COVID-19, у Дніпропетровській медичній академії студенти-провізори 4 курсу, як громадяни України, так і іноземці, мали змогу підготуватися та скласти ЄДКІ, який мав дві складові, такі, як: ліцензійний інтегрований комплексний іспит «Крок 1» та англійська мова професійного спрямування. Аналіз отриманих результатів дозволив виявити як недоліки, так і переваги при підготовці та самопідготовці студентів в академії і привернути увагу до рішення проблемних питань. Таке комплексне оцінювання профільних знань студентів-провізорів дозволяє виявити слабкі сторони процесу навчання і надає можливість підвищити ефективність навчання в академії для інтегрування вітчизняних фахівців у світову медицину.
\end{abstract}

Ключові слова: єдиний державний кваліфікаційний іспит; провізор; фахівець; інтегрований іспит.

Abstract. The article analyzes the results of the Unifi ed State Qualifi cation Examination (USQE) implementation in order to assess the pharmacy students' education level during the Krok-1 licensed integrated examination and to compare these results with the national indicators. Despite the fact that in 2020 for the first time introduced distance learning for the period of full lockdown in Ukraine due to the prevalence of COVID-19 infection has been introduced in Ukraine, both Ukrainian and foreign third year pharmacy students have had the USQ examination at Dnipropetrovsk Medical Academy which included two components: Krok-1 licensed integrated examination and professional English. The analysis of the obtained results has revealed shortcomings and the advantages for preparing and passing of the student training program and drawn an attention to the solution to problematic issues. This comprehensive assessment of the pharmacy students' profile knowledge allows us to identify the training programs' shortcomings and provides an opportunity to increase the effectiveness of study at the academy in order to integrate Ukrainian specialists in the world medicine.

Key words: unified state qualification examination; pharmacist; specialist; integrated exam.

Вступ. Сучасне суспільство стрімко розвивається на тлі глобалізації, що обумовлює появу нових вимог до фахівців будь-якої сфери діяльності. Ці процеси не обійшли й медицину та фармацію. Фахівець повинен володіти такими базовими компетенціями, як вміння орієнтуватися в масиві ін-

(C) Т. М. Потапова, Н. В. Логвиненко формації, що надходить, та вміння діяти в умовах нестачі необхідних інформаційних даних, здатність до абстрактного мислення, аналізу та синтезу, і застосування знань у практичних ситуаціях. Оскільки сучасний роботодавець надасть перевагу тому випускнику, який швидко пристосовується до нестабільних, постійно мінливих умов суспільства, ви- 
пускнику, який націлений на вирішення складних, нестандартних питань, хто може вільно та вправно користуватися ресурсами Інтернету.

Сучасному фахівцю необхідне постійне оновлення отриманих знань та навичок, що підтверджує концепцію «освіта протягом життя», замість «освіта на все життя». Протягом всієї своєї трудової діяльності фахівець повинен самостійно оцінювати свої реальні можливості і потреби та постійно вдосконалюватись, підвищувати рівень професійної та особистої компетентності, оцінювати свої досягнення.

Також невпинно зростає роль вищої школи у формуванні та ефективному використанні наукового та інноваційного потенціалу. Вища професійна освіта повинна відповідати сучасним потребам суспільства, таким, як можливість поєднання навчання 3 професійною діяльністю, доступність та можливість отримання безперервної освіти. Для цього необхідно створити відповідне комунікаційне середовище, яке спроможне вирішити ці задачі. Такий виклик сучасності спонукає викладачів вищої школи набувати навичок працювати 3 новітніми інноваційними, інформаційно-комунікаційними і комп’ютерними технологіями.

На сьогодні (в умовах карантину) ми можемо спостерігати перехід від традиційної форми навчання, отримання освіти, до дистанційної моделі. Такий перехід змушує професорсько-викладацький склад переглянути та модифікувати не тільки методологію викладання, але й опанувати у короткий термін навички тьюторства та роботи 3 різноманітними інтернет-платформами. За цих умов також велика відповідальність за навчальний процес лягає на плечі здобувача вищої освіти. Оскільки мотивація і зацікавленість у своїй майбутній професії залежить, насамперед, від нього. Окрім цього, дистанційне навчання підвищує ефективність самостійної роботи студента, відкриває нові можливості для творчості, придбання та закріплення різних професійних навичок.

Згідно з дослідженнями у Дніпропетровській державній академії [1], до переваг дистанційної моделі навчання можна віднести:

- навчання стає більш доступним, бо студенту немає потреби долати великі відстані до університету та витрати на транспорт;

- студент має змогу відвідувати заняття з будьякого зручного місця, що важливо для сучасної молодої людини;

- інтерактивність, у свою чергу, підвищує зацікавленість та мотивацію до здобуття освіти;
- надає можливість креативного, творчого підходу до опанування професійних навичок та знань;

- доступність матеріалу на інтернет-ресурсах, можливість самостійної підготовки та самоперевірки у будь-який зручний для здобувача час.

Але $є$ й недоліки, головний - це відсутність «живого» контакту з викладачем, його підтримки, опіки. Значне збільшення завдань та брак часу для самостійного виконання. Деякі студенти можуть виявляти академічну недоброчесність. Також дуже не рідко і здобувач, і викладач страждають від технічних проблем.

У таких умовах викладачу важко оцінити здобуті знання, а найважливіше - провести підсумковий контроль. Це стосується, перш за все, єдиного державного кваліфікаційного іспиту «Крок 1. Фармація». Але незважаючи на вимушені заходи, продиктовані карантином, Центр тестування провів цей іспит серед студентів медичних закладів вищої освіти України.

Мета статті - аналіз результатів проведення єдиного державного кваліфікаційного іспиту «Крок 1. Фармація, промислова фармація» в умовах дистанційного навчання під час пандемії, порівняння отриманих результатів з національними показниками та якості самопідготовки здобувачів-провізорів у Дніпропетровській медичній академії до іспиту.

Теоретична частина. Система забезпечення якості, що реалізована для вищої фармацевтичної освіти України на галузевому рівні, включає тестові ліцензійні інтегровані іспити, які в різному статусі реалізуються з 1998 р. Інтегрований ліцензійний тестовий іспит «Крок», призначений для визначення професійної компетентності фахівців, проводиться Державною організацією «Центр тестування професійної компетентності фахівців 3 вищою освітою напрямів підготовки «Медицина» i «Фармація» при Міністерстві охорони здоров’я України».

Результати складання ліцензійного іспиту «Крок» здобувачами вищої освіти - це важливий рейтинговий показник якості освітнього процесу. Кожного року за результатами складання першого етапу ЄДКІ студентами громадянами України, а також студентами, які є громадянами інших держав, проводиться інформаційно-аналітичне дослідження, що потребує опрацювання даних ДО «Центр тестування». Результатом інформаційно-аналітичних досліджень є формування проблеми, а вже згодом шляхи вирішення та вдосконалення при підготовці до ліцензійних іспитів. 
«Крок 1. Фармація» - іспит із загальнонаукових дисциплін, проводиться після закінчення 3-го курсу, його структура складається з дисциплін природничо-наукового циклу:

- $з$ неорганічної хімії;

- $з$ органічної хімії;

- $з$ аналітичної хімії;

- $з$ фізичної та колоїдної хімії;

- $з$ біохімії;

- $з$ ботаніки;

- $з$ фармакології;

- $з$ патологічної фізіології;

- $з$ мікробіології.

Зважаючи на поширення COVID-19, відповідно до рішення Уряду України від 11.03.2020 р. № 211 «Про запобігання поширенню на території України коронавірусу COVID-19», наказу MO3 України від 11.03.2020 р. № 1/9-154 [4] щодо запровадження карантину для всіх типів закладів освіти наказом № 49-ОД від 11.03.2020 р. «Щодо готовності медичної академії для проведення профілактичних заходів з недопущення поширення випадків COVID-19 у м. Дніпро» та наказом № 60-ОД від 11.03.2020 р. «Про організацію освітнього процесу в академії в умовах запобіганню коронавірусу» в академії введено карантинний режим та терміново впроваджено дистанційне навчання [2, 3].

Умови дистанційного навчання стали справжнім випробуванням у спілкуванні студент - викладач, створивши відповідну структуру для забезпечення зв’язку зі студентами, визначивши відповідну методику, прийнятну для системи дистанційного навчання, а також плани підтримки студентів в умовах онлайн-зв'язку із викладачами академії, було організовано процес неперервної перевірки відповідності та якості запропонованої дистанційної навчальної програми.

Дніпровський державний медичний університет для організації навчання, як в умовах світової пандемії, так і в звичному режимі, активно впроваджує досить розповсюджену та популярну в освітньому середовищі платформу електронного навчання Moodle. Moodle (модульно об’єктно-орієнтоване динамічне навчальне середовище) - вільна система управління навчанням, яка розповсюджується за ліцензією GNU General Public License. Програма Moodle перекладена десятками мов, також і українською, та використовується в 197 країнах світу. За допомогою цієї платформи здобувачі мають змогу якісно підготуватися як до заняття, так і до складання тестового іспиту Крок 1, 2.
Контент Moodle постійно поповнюється, оновлюється, змінюється викладачами, також поповнюється база тестів. Що надає велику можливість здобувачу самостійно перевіряти та контролювати рівень своїх знань, бачити свої помилки і проводити роботу над ними шляхом тестування.

Складним етапом була розробка програми оцінювання й коментування всіх компонентів навчання і визначення, які з них можна включити у процес дистанційного навчання, але, незважаючи на це, час практичної підготовки та індивідуальний підхід до кожного студента, а також можливість приділити більше часу для теоретичного засвоєння матеріалу, дозволили підготувати студентів до складання ліцензійного іспиту належним чином, про що свідчать показники Центру тестування.

За даними Центру тестування при Міністерстві охорони здоров’ я України, середній бал складання іспиту вітчизняними студентами у 2020 р. становив 70,1 \% [5]. Серед вітчизняних студентів-провізорів Дніпропетровської медичної академії тільки один студент не склав Крок 1 (8,3 \%), що у 2 рази нижче національного показника (17,7 \%) [3].

У таблиці 1 наведено дані національного показника результатів складання іспиту за субтестами за 2019 та 2020 роки. Найгірший показник (58,2%) припадає на органічну хімію, а фармакологія продемонструвала найкращий результат (79,7 \%). Також можна відмітити не дуже високий рівень складання іспиту з фармацевтичної ботаніки (66,1%) та мікробіології (67,9 \%), але достатній, щоб перетнути мінімальний поріг.

Таблиця 1. Національний показник результатів складання тестового іспиту «Крок 1»

студентами-громадянами України за субтестами

\begin{tabular}{|c|c|c|c|c|c|c|c|c|c|}
\hline 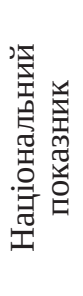 & 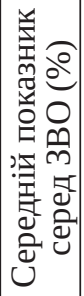 & 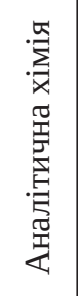 & 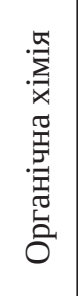 & 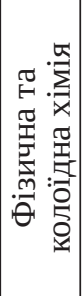 & 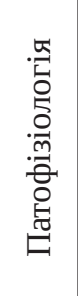 & 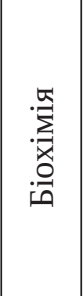 & 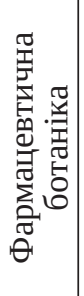 & 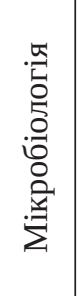 & 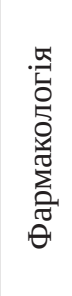 \\
\hline 2020 & 70,1 & 71,1 & 58,2 & 72,2 & 70,3 & 74,8 & 66,1 & 67,9 & 79,7 \\
\hline סחק & 69,6 & 71,2 & 60,1 & 58,4 & 68,9 & 74,6 & 72,6 & 73,0 & 77,9 \\
\hline
\end{tabular}

У порівнянні з торішніми результатами дещо знизилися показники з фармацевтичної ботаніки та мікробіології, а результати складання фізичної та колоїдної хімії, хоча і незначно, але виявили тенденцію до покращення (у 1,2 раза). Можливо, це пов’язано з тим, що здобувач розгубився при пе- 
реході на повне дистанційне навчання, коли ще не були надбані навички абсолютно самостійної роботи, без емоційної підтримки викладача, та в умовах напруженої епідеміологічної ситуації у світі. Також на той момент було дуже велике навантаження на інтернет-ресурси в цілому і не всі здобувачі мали вільний доступ до Інтернету та якісні гаджети. Тому здобувачі не мали змоги якісно підготуватися до складання у досить короткий термін (з березня по червень), але, попри всі незгоди, все ж таки продемонстрували непоганий результат.

Загалом по Україні, ситуація складання інтегрованого іспиту, в умовах карантину та дистанційного навчання, залишається стабільною, з незначними коливаннями.

Вітчизняні студенти-провізори показали низький рівень знань $з$ хімічних (органічна і аналітична хімії) та медико-біологічних наук (патологічна фізіологія) (табл. 2). В той самий час фармакологія, фізична та колоїдна хімія, біологічна хімія мають достатньо високий рівень - 80,6 \%, 74,5 \% 71,3 \% відповідно. Якщо порівняти з результатами складання іспиту у 2019 р., можна відмітити тенденцію до зниження показників майже по всіх субтестах, окрім фізичної та колоїдної хімії (що відповідає національному показнику).

Таблиця 2. Показник результатів складання тестового іспиту «Крок 1» студентами-громадянами України

у Дніпропетровській медичній академії

\begin{tabular}{|c|c|c|c|c|c|c|c|c|c|}
\hline \multirow[b]{2}{*}{ 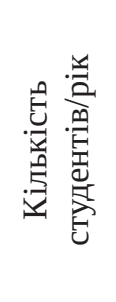 } & \multirow[b]{2}{*}{$\frac{\overparen{E}}{\stackrel{\partial}{0}}$} & \multicolumn{8}{|c|}{ Субтести (\%) } \\
\hline & & 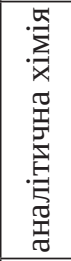 & 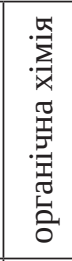 & 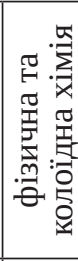 & 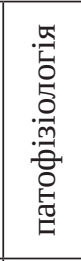 & 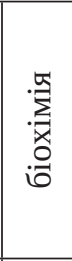 & 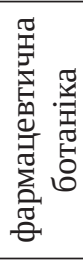 & 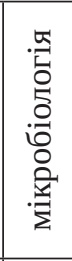 & 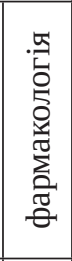 \\
\hline $12 / 2020$ & 65,6 & 56,3 & 51,2 & 74,5 & 59,7 & 71,3 & 64,1 & 69,0 & 00,0 \\
\hline 9/2019 & 69,9 & 76,7 & 52,4 & 52,3 & 59,3 & 80,2 & 75,7 & 81,5 & 80,4 \\
\hline
\end{tabular}

Середній показник кількості іноземних студентів, мова навчання яких російська/українська, які не склали іспит «Крок 1», по країні становить 31,1 \%.

Серед іноземних студентів-провізорів ДМА не склало 10,8 \% Крок 1, що майже у 3 рази нижче національного показника, та всі склали іноземну (російську мову).

Як видно з наведених даних (табл. 3), найнижчі показники припадають на органічну хімію (55,1%), фармацевтичну ботаніку (59,6 \%) та мікробіологію (57,7 \%). Але, на відміну від вітчизняних студентів, іноземці показали дуже високий рівень під- готовки з фармакології, патофізіології, біохімії та аналітичної хімії.

Таблиця 3. Показник результатів складання тестового іспиту «Крок 1» студентами-громадянами іноземних країн у Дніпропетровській медичній академії

\begin{tabular}{|c|c|c|c|c|c|c|c|c|c|}
\hline \multirow[b]{2}{*}{ 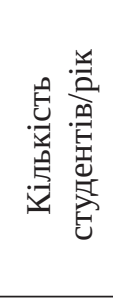 } & \multirow[b]{2}{*}{ 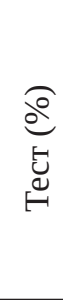 } & \multicolumn{8}{|c|}{ Субтести (\%) } \\
\hline & & 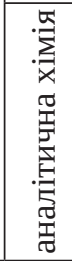 & 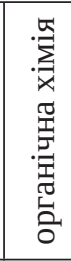 & 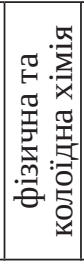 & 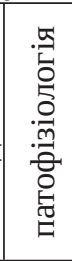 & 氛 & 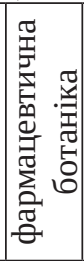 & 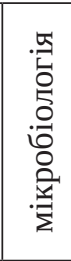 & 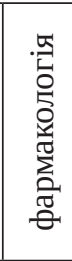 \\
\hline $37 / 2020$ & 69,0 & 73,0 & 55,1 & 73,8 & 64,6 & 80,3 & 59,6 & 57,7 & 86,1 \\
\hline $12 / 2019$ & 67,1 & 78,2 & 54,8 & 49,5 & 53,2 & 78,7 & 78,6 & 70,4 & 73,0 \\
\hline
\end{tabular}

Аналізуючи отримані дані, важливо зазначити, що іноземні студенти позитивно сприйняли умови дистанційного навчання, що відобразилося, хоча i не дуже різко, на показниках результатів більшості субтестів. Відповідальний підхід до самоосвіти, потужна мотивація та достатня кількість часу для опанування знань принесли позитивні результати.

Висновки та перспективи подальших досліджень. 1. Щорічні огляди інформаційно-аналітичних досліджень результатів субтестів дозволяють розглянути недоліки та переваги і внести зміни до програм навчальних дисциплін, а в подальшому внести деякі корективи до структури ОПП, яка дозволяє сформувати та розвинути у здобувачів вищої освіти комплекс знань, навичок та вмінь, які $є$ необхідними для подальшої професійної діяльності у сфері організації забезпечення населення лікарськими засобами.

2. Аналіз успішності складання студентами «Крок 1» дозволяє зробити висновки щодо успішної моделі впровадження дистанційного навчання в освітній процес. Стосовно підготовки теоретичної частини матеріалу можна зазначити навіть позитивну динаміку і точно вказати на переваги дистанційного навчання. Якщо звернути увагу на заняття 3 практичної підготовки, то тут звичайно недостатній безпосередній контакт між персональним викладачем, що маємо на результатах тестування, які потребують удосконалення практичних навичок. Також аналіз результатів тестування з умов звичайного та дистанційного навчання дозволить прогнозувати результати цього іспиту в 2020/2021 н. р. й надалі, визначити на основі цього аналізу прогнозовану успішність студентів при створенні науково обгрунтованої системи освіти та умов, які зможуть впровадити blended, тобто поєднання офлайн- та онлайн-навчання. 


\section{Список літератури}

1. Височина І. Л. Дистанційне навчання на кафедрі сімейної медицини Д3 «Дніпропетровська медична академія МОЗ України» очима студентів-медиків другого курсу (аналіз результатів анонімного анкетування) / І. Л. Височина, І. В. Авраменко, Н. С. Башкірова // Медична освіта. - 2020. - № 4. - С. 5-9.

2. Корбут О. Г. Дистанційне навчання: моделі, технології, перспективи / О. Г. Корбут // Новітні освітні технології в контексті Євроінтеграції : матеріали Х Міжнар. наук.-практ. конф. (Київ, 14 січня 2015 р.). - К. : КПІ, 2015 [Електронний ресурс]. - Режим доступу : http:// confesp.fl.ua/ru/node/1123.

\section{References}

1. Vysochyna, I.L., Avramenko, I.V., \& Bashkirova, N.S. (2020). Dystantsiine navchannia na kafedri simeinoi medytsyny DZ "Dnipropetrovska medychna akademiia MOZ Ukrainy” ochyma studentiv-medykiv druhoho kursu (analiz rezultativ anonimnoho anketuvannia) [Distance learning at the department of family medicine at SI "Dnipropetrovsk Medical Academy of the Ministry of Health of Ukraine”, through the eyes of second-year medical students (analysis of the results of the anonymous survey)]. Medychna osvita - Medical Education, 4, 5-9 [in Ukrainian].

2. Korbut, O.G. (2015). Dystantsiine navchannia: modeli, tekhnolohii, perspektyvy [Distance learning: models, technologies, perspectives]. Novitni osvitni tekhnolohii $v$ konteksti Yevrointehratsii : materialy Kh Mizhnar. nauk.prakt. konf. - The latest educational technologies in the
3. Сайт Дніпровського державного медичного університету [Електронний ресурс]. - Режим доступу : https:// www.dsma.dp.ua.

4. Сайт Міністерства освіти і науки України [Електронний ресурс]. - Режим доступу : https://mon.gov.ua/storage/ app/media/news/\%D0\%9D\%D0\%BE\%D0\%B2\%D 0\%B8 \%D0\%BD\%D0\%B8/2020/03/11/1_9-154.pdf.

5. Сайт Тест-центру при Міністерстві охорони здоров'я [Електронний ресурс]. - Режим доступу : https://www.testcentr.org.ua/ai/2020/ai-edki-krok1-pharmeng-13102020.pdf.

context of European integration: materials $X$ between people Scientific-practical Conf. Kyiv: KPI. Retrieved from: http:// confesp.fl.ua/ru/node/1123 [in Ukrainian].

3. Sait Dniprovskoho derzhavnoho medychnoho universytetu [Website of Dnipro State Medical University]. Retrieved from: https://www.dsma.dp.ua [in Ukrainian].

4. Sait Ministerstva osvity i nauky Ukrainy [Website of the Ministry of Education and Science of Ukraine]. Retrieved from: https://mon.gov.ua/storage/app/media/news [in Ukrainian].

5. Sait Test-tsentru pry Ministerstvi okhorony zdorovia [Website Test centr by Ministry of Health of Ukraine]. Retrieved from: https://www.testcentr.org.ua/ai/2020/aiedki-krok1-pharm-eng-13102020.pdf [in Ukrainian]. 